\title{
SAUDAÇÃO AOS FORMANDOS: DISCURSO DO PATRONO *
}

Yoriko Kamiyama**

Caros Formandos,

A Escola de Enfermagem está em festa, neste dia de gala em que novo grupo de jovens enfermeiros dela parte para a nobre missão de elevar o nivel de saúde e bem-estar da sociedade.

Após quatro anos de árduos estudos e de lutas pelas glórias de um ideal, chegastes, triunfantes, ao final do vosso curso.

Ontem - o rigor dos estudos, a pontualidade e assiduidade às aulas e estágios, os trabalhos que exigiam muitas noites de vigília. Hoje - a recompensa, o regozijo, as láureas que enchem de imensa alegria o vosso jovem coração.

Vossos pais que sempre deram apoio, estimulo e orientação e que tudo fizeram para proporcionar a vitória que ora alcançais, podem cumprimentar-vos felizes, como felizes e emocionados podeis abraçá-los, com gratidão.

A vós que vos tornastes enfermeiros no Ano I da Era em que a humanidade busca a meta social "Saúde para Todos no Ano 2.000", abrem-se novos horizontes no campo profissional, repletos de aventuras, desafios, lutas, problemas e necessidades que exigem força, inspiração e coragem para o cumprimento do complexo e envolvente dever de "assistir o ser humano no atendimento de suas necessidades básicas" no plano biológico, psicológico e social.

Ajudar a vir ao mundo pequeninos seres humanos, semear nas consciências dos homens seus direitos e deveres em relação à saúde; assistir ao enfermo em estado grave que necessita de cuidados intensivos; amenizar a angústia e os temores daqueles que se despedem da vida, são tarefas que requerem, além de ciência, arte e tecnologia, o envolvimento do Eu Terapêutico, compromisso sem o qual, podereis "estar" enfermeiro, mas não "ser" enfermeiro.

Para assumir e renovar tal compromisso a cada momento de vossa existência, nada mais adequado e oportuno que a mensagem contida no poema "TORNAR-SE" da saudosa Prof. " Dra. Wanda de Aguiar Horta.

* Discurso pronunciado em 16 de julho de 1981, a um grupo de formandos da Escola de Enfermagem da USP.

* Professor Adjunto do Departamento de Enfermagem Médico-Cirúrgica da EEUSP, disciplina Enfer. magem em Doenças Transmissíveis. 


\section{TORNAR-SE}

Um ser enfermeiro

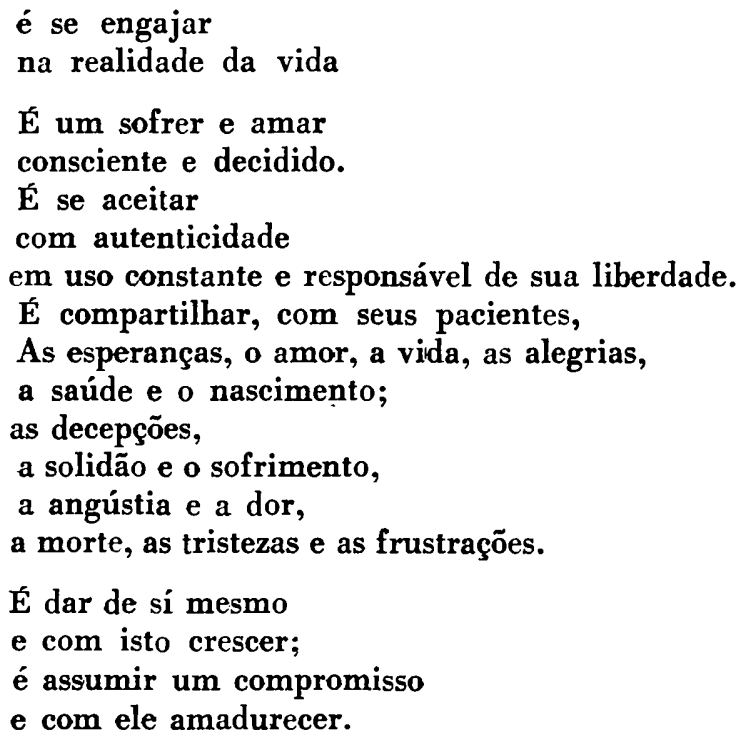

Prezados Formandos,

Vossas potencialidades estão preparadas para os altos vôos reservados pelo destino; porém lembrai-vos de que o triunfo virá para aqueles que reconhecem a necessidade de contínua atualização, estudo e aperfeiçoamento.

Muito honrada e sensibilizada com o convite com que me distinguistes - Patrono dessa turma - meus sinceros e respeitosos cumprimentos e votos de pleno êxito na carreira profissional.

Que Deus acompanhe vossos passos e cubra com a sua proteção a vossa jornada na consolidação da enfermagem como ciência, no alívio e conforto das pessoas que dela necessitam e no desenvolvimento das comunidades a que ides SERVIR! 